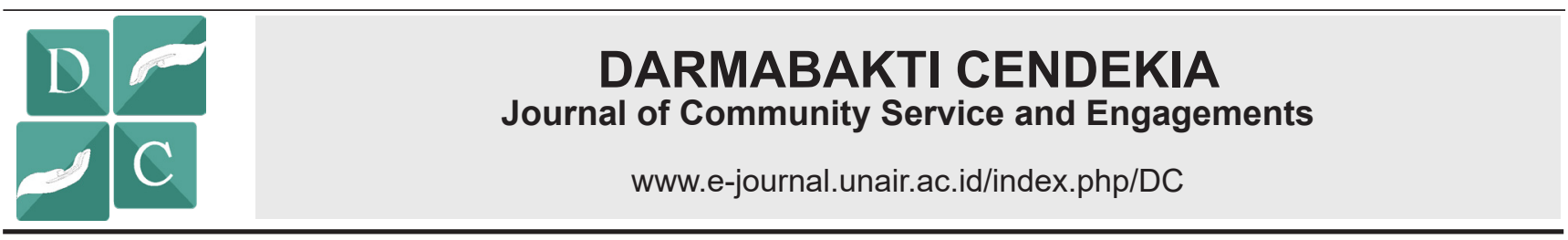

\title{
EMPOWERMENT OF THE ROADSIDE COMMUNITIES IN SAMIRPLAPAN GRESIK THROUGH GARBAGE BANK
}

\author{
PEMBERDAYAN MASYARAKAT PINGGIR JALAN RAYA \\ SAMIRPLAPAN GRESIK MELALUI BANK SAMPAH
}

\section{Scope:}

Socioeconomic

\author{
Khuliyah Candraning Diyanah ${ }^{1 *}$, Nuzulul Kusuma Putri² ${ }^{2}$ Aditya Sukma Pawitra ${ }^{1}$ \\ ${ }^{1}$ Department of Environmental Health, Faculty of Public Health, Universitas Airlangga, Surabaya-Indonesia \\ ${ }^{2}$ Department of Health Administration and Policy, Faculty of Public Health, Universitas Airlangga, Surabaya-Indonesia
}

\begin{abstract}
A B S T R A C T
Background: The partnership program with the community was held by establishing a garbage bank and a waste management center in Samirplapan Village, Duduk Sampeyan District, Gresik. Starting with the problem of partners, the large amount of waste generated due to being on the edge of the inter-city connecting road of Gresik- Lamongan that is often passed by many vehicles. The community still has not the knowledge to manage waste becomes more economic value. Purpose: this activity aimed to help the community in utilizing inorganic waste to be more economically valuable through the garbage bank system. While organic waste will be processed in each household into compost using the Takakura method. Methods: This activity ran for 6 months, beginning with the socialization of garbage banks to village communities, technical training, implementation of the garbage bank system, monitoring and evaluation, and development. The targets of this partnership program are PKK (community that focused on woman welfare) and community in Samirplapan village, which are mostly housewives. Results: A Garbage bank in Samirplapan village has been formed with 35 members, participants actively participate in garbage bank activities, and the knowledge of participants has also increased. In addition, participants were given training in handicrafts made from inorganic waste and how to make compost with Takakura. Conclusion: Garbage bank is one form of solution in handling waste problems by applying the principle of $3 R$ (Reduce, Reuse, Recycle) based on community.
\end{abstract}

\section{A B S T R A K}

Latar Belakang: Program kemitraan dengan masyarakat dilaksanakan dengan mendirikan bank sampah di Desa Samirplapan, Kecamatan Duduk Sampeyan, Gresik. Masalah yang ada adalah banyaknya sampah yang dihasilkan karena berada di pinggir jalan penghubung antar kota Gresik-Lamongan yang sering dilewati banyak kendaraan. Masyarakat masih belum memiliki pengetahuan untuk mengelola sampah menjadi lebih bernilai ekonomi. Tujuan: kegiatan ini bertujuan membantu masyarakat dalam memanfaatkan limbah anorganik agar lebih bernilai secara ekonomis melalui sampah sistem bank. Sementara sampah organik akan diolah di setiap rumah tangga menjadi kompos menggunakan metode Takakura. Metode: Kegiatan ini berlangsung selama 6 bulan, dimulai dengan sosialisasi bank sampah kepada masyarakat desa, pelatihan teknis, penerapan sistem bank sampah, pemantauan dan evaluasi, dan pengembangan. Sasaran program kemitraan ini adalah PKK (komunitas yang fokus pada kesejahteraan perempuan) dan masyarakat di Desa Samirplapan, yang sebagian besar adalah ibu rumah tangga. Hasil: Bank sampah di Desa Samirplapan telah terbentuk dengan jumlah anggota 35 peserta, peserta aktif mengikuti kegiatan bank sampah, pengetahuan peserta juga meningkat. Selain itu peserta telah diberikan pelatihan kerajinan tangan dari sampah anorganik dan cara membuat kompos dengan Takakura. Kesimpulan: Bank sampah adalah salah satu bentuk solusi dalam penanganan masalah sampah dengan menerapkan prinsip $3 R$ (Reduce, Reuse, Recycle) berbasis komunitas.

\section{A RT I CLE INFO}

Recieved 1 October 2019 Accepted 4 November 2019 Online 20 December 2019

*Correspondence(Korespondensi): Khuliyah Candraning Diyanah

E-mail:

k.c.diyanah@fkm.unair.ac.id

Keywords:

Garbage Bank; Community; Inorganic Waste; Organic Waste

Kata kunci:

Bank sampah; Komunitas;

Sampah anorganik; sampah organik 


\section{PENDAHULUAN}

Desa Samirplapan merupakan salah satu desa di wilayah Kecamatan Duduksampeyan, Kabupaten Gresik berjarak kurang lebih $1 \mathrm{~km}$ dari pusat Kantor Kecamatan dan $10 \mathrm{~km}$ dari Kantor Kabupaten Gresik. Berdasarkan hasil analisis situasi, empat aspek telah ditinjau yaitu kekuatan (Strength), kelemahan (Weakness), peluang (Opportunity), dan ancaman (Threat). Desa Samirplapan memiliki beberapa aspek kekuatan yakni aktifnya masyarakat dalam melaksanakan kegiatan sosial. Selain itu, pejabat setempat mulai dari ketua RT, ketua RW, hingga lurah juga mendukung setiap kegiatan pemberdayaan yang diadakan di desa. Kekurangan yang dimiliki desa ini adalah masih kurangnya pemahaman masyarakat terkait pengelolaan sampah yang bisa bernilai ekonomis.

Sementara jika dilihat dari faktor eksternal, terdapat beberapa ancaman bagi desa ini yakni keberadaan yang tepat di pinggir Jalan Raya GresikBabat sebagai jalan raya utama menuju Lamongan. Hal tersebut mengakibatkan desa ini dilalui oleh berbagai jenis kendaraan dalam waktu 24 jam, sehingga timbul banyaknya sampah yang dibuang sembarangan di pinggir jalan. Pembuangan sampah sembarangan dapat menjadi sarang nyamuk yang dapat menjadi vektor penyakit, salah satunya adalah penyakit demam berdarah. Hal tersebut dibuktikan dengan masih sering ditemukannya penyakit demam berdarah di Desa Samirplapan. Namun letak desa Samirplapan juga sekaligus bisa menjadi peluang. Keberadaan karang di pinggir jalan raya cukup strategis untuk dimanfaatkan sebagai tempat persinggahan yang nyaman oleh masyarakat yang sedang melakukan perjalanan jauh.

Berdasarkan penjabaran masalah di atas, masalah mitra pada kegiatan ini adalah belum adanya pengelolaan sampah terorganisir yang dapat menambah penghasilan masyarakat di desa Samirplapan. Hal ini dipengaruhi oleh terbatasnya pengetahuan masyarakat tentang manfaat ekonomis sampah dan cara pengolahannya. Oleh karena itu, program kemitraan ini difokuskan untuk melakukan pelatihan dan pemberdayaan melalui sistem bank sampah, sehingga masyarakat dapat memperoleh manfaat ekonomis sampah dengan cara menabung dan mengolah sampah. Dalam upaya mendukung pelaksanaan bank sampah di masyarakat, pemerintah telah mengeluarkan Peraturan Menteri Negara Lingkungan Hidup Nomor 13 Tahun 2012 tentang Pedoman Pelaksanaan Reduce, Reuse, dan Recycle melalui Bank Sampah. Pada Peraturan ini, telah dicantumkan: (a) persyaratan bank sampah; (b) mekanisme kerja bank sampah; (c) pelaksanaan bank sampah; dan (d) pelaksana bank sampah. Adanya pengaturan pengelolaan sampah ini bertujuan untuk menjaga kelestarian fungsi lingkungan hidup dan kesehatan masyarakat serta menjadikan sampah sebagai sumber daya (Peraturan Pemerintah Republik Indonesia No. 81, 2012).

Permasalahan pada desa mitra dapat diidentifikasi sebagai berikut: (1) Rendahnya tingkat pendidikan masyarakat, (2) Tingginya tingkat kemiskinan dan angka ibu rumah tangga yang tidak bekerja, (3) Kurangnya kesadaran masyarakat mengenai pengelolaan sampah serta hidup bersih dan sehat.

Tujuan dari diadakannya program kemitraan kepada masyarakat iniadalah memberikan pelatihan kepada masyarakat desa Samirplapan agar mampu memilah dan membedakan antara sampah organik dan anorganik, mampu melakukan pengolahan sampah organik secara pribadi dengan metode takakura, serta menghasilkan tabungan sampah melalui bank sampah. Semua program ini selain untuk mengurangi timbulan sampah, menciptakan lingkungan yang bersih (Rozak, 2014).

\section{METODE}

Solusi yang ditawarkan sebagai upaya untuk menanggulangi masalah sampah pada desa Samirplapan yakni sebagai berikut: (1) Mengadakan sosialisasi dan penggalangan komitmen untuk mengimplementasikan bank sampah oleh masyarakat, (2) Melakukan pelatihan tentang sistem bank sampah, (3) Melakukan pelatihan tentang pengelolaan hasil bank sampah dan pengolahan sampah organik, serta (4) Menciptakan kerangka kerjasama dalam pengelolaan hasil bank sampah.

Sebelum bank sampah diimplementasikan, pengurus bank sampah yang telah dibentuk sebagai kader diminta untuk memaparkan rencana pelaksanaan kepada penduduk. Setelah kader memaparkan rencana, maka langkah selanjutnya adalah melatih ibu rumah tangga untuk dapat menjadi pengelola bank sampah. Implementasi bank sampah akan dilakukan oleh ibu rumah tangga di Samirplapan dan akan dimonitoring oleh pengurus bank sampah. Untuk dapat mendistribusikan hasil bank sampah maka akan ada 3 kegiatan yang akan dilakukan yakni:

a. Pelatihan tentang kerajinan hasil pengelolaan bank sampah. Ibu rumah tangga selain diajari tentang mekanisme bank sampah, juga diajari membuat ketrampilan dari sampah anorganik untuk meningkatkan nilai ekonomis dari hasil bank sampah.

b. Pelatihan mengolah sampah organik dengan metode Takakura. Selain memilah sampah anorganik, masyarakat juga diminta menyisihkan sampah organiknya untuk dimanfaatkan menjadi kompos. Takakura merupakan metode pengolahan sampah organik di rumah yang 
mudah dan tidak menyita waktu.

c. Menciptakan kerjasama dalam pengelolaan hasil bank sampah. Pengabdian masyarakat ini juga menyiapkan mekanisme distribusi hasil bank sampah termasuk tidak hanya pada pengepul barang bekas, namun juga distribusi hasil kerajinan tangan pengelolaan bank sampah.

Pendekatan yang digunakan dalam menjalankan program bank sampah melalui perangkat desa yaitu Lurah dan Ibu-Ibu PKK. Kedua unsur masyarakat tersebut dipilih karena dianggap mempunyai peran penting dalam mengajak dan mempengaruhi warganya untuk berpartisipasi dalam bank sampah. Bertambahnya partisipasi masyarakat Desa Samirplapan bisa ditunjukkan dengan terus meningkatnya jumlah nasabah dari bank sampah yang kini telah berjumlah 35 orang.

Harapan dari diadakannya kegiatan bank sampah di Desa Samirplapan adalah meningkatnya partisipasi dan keikutsertaan dari masyarakat Desa dalam menjalankan dan menjadi nasabah bank sampah. Antusias masyarakat Desa Samirplapan diharapkan juga meningkat seiring dengan berjalannya kegiatan bank sampah, tidak hanya diikuti oleh Ibu-lbu PKK namun juga seluruh masyarakat Desa Samirplapan.

Bank sampah selain bisa membantu mengurangi sampah di lingkungan Desa Samirplapan, juga membantu memberikan pendapatan tambahan bagi masyarakat disana. Berdasarkan hal tersebut, momentum ini bisa menjadi pemicu awal bagi masyarakat disana dalam berpartisipasi di kegiatan bank sampah. Mekanisme dari sistem bank sampah untuk memilah dan menabung sampah, kemudian bisa menjadi kebiasaan bagi masyarakat Desa Samirplapan.

Evaluasi dari pelaksanaan program bank sampah dilakukan 2 minggu sekali untuk memantau terus keberlanjutan programnya. Sebagai salah satu program baru di Desa Samirplapan, maka evaluasi dan pemantauan perlu dilakukan secara intensif untuk penyempurnaan program. Harapan ke depan, sebelum Desa Samirplapan dibiarkan mandiri untuk mengelola bank sampah, masyarakat telah memiliki program yang sudah teroganisir dan tersistem dengan baik. Dengan demikian, hasil evaluasi dapat menjamin keberkelanjutan program untuk terus berjalan tanpa memerlukan bantuan dari pihak lain.

\section{HASIL DAN PEMBAHASAN}

Desa Samirplapan merupakan salah satu desa yang berada di kecamatan Duduk Sampeyan, Gresik. Berdasarkan hasil observasi dan data RPJM Desa Samirplapan berikut merupakan gambaran umum mitra:

\section{Sosial}

Tingkat

pendidikan

masyarakat

Desa
Samirplapan masih terbilang cukup rendah, dimana persentase tertinggi tingkat pendidikan warga Desa berada pada tamat sekolah SD yaitu 33\%, kemudian disusul dengan tamat sekolah SMP 29\%, tamat sekolah SMA $25 \%$, usia pra sekolah $6 \%$, dan tamat Perguruan Tinggi hanya sebesar $2 \%$. Meskipun demikian, warga Desa Samirplapan memiliki semangat yang luar biasa terkait kegiatan Desa. Hal tersebut dibuktikan dengan masih aktifnya Karang Taruna Desa dalam mendukung segala kegiatan yang dapat memajukan Desa Samirplapan.

\section{Ekonomi}

Berdasarkan segi ekonomi, sebanyak 30\% warga Dusun Samir dan 30\% warga Dusun Plapan mengalami kemiskinan dikarenakan banyaknya warga yang tidak memiliki pekerjaan tetap dan minimnya keterampilan yang dimiliki. Sementara itu, berdasarkan data penduduk desa Samirplapan tahun 2013, sebesar $12 \%$ msyarakat tidak memiliki pekerjaan. Angka pengangguran tersebut didominasi oleh ibu-ibu rumah tangga yang ada di Desa Samirplapan, tingginya angka ibu rumah tangga tersebut dipengaruhi oleh salah satu faktor yaitu kebudayaan desa Samirplapan yang didominasi oleh budaya agama islam, dan budaya adat Jawa.

\section{Kesehatan dan Lingkungan}

Desa Samirplapan memiliki lokasi yang berada tepat di pinggir Jalan Raya Gresik-Babat yang merupakan jalur utama menuju Lamongan. Oleh karena itulah, jalan raya ini sering dilalui oleh banyak kendaraan, baik kendaraan umum seperti bis kota dan angkot, maupun kendaraan pribadi seperti mobil pribadi dan juga truk pengangkut barang. Jalan raya ini sering mengalami kemacetan akibat banyaknya volume kendaraan yang melintas, sehingga banyak pengendara yang membuang sampah sembarangan di pinggir jalan Desa Samirplapan ini dan menghasilkan banyak timbunan sampah di pinggir jalan desa ini. Selain itu, kesadaran masyarakat mengenai sampah juga masih sangat kurang, penduduk Desa Samirplapan juga masih sering membuang sampah sembarangan dan kurang peduli dengan sampah yang ada sekitar tempat tinggal mereka.

Berdasarkan segi kesehatan dan lingkungan permasalahan di Desa Samirplapan terletak pada pembuangan limbah sampah yang belum baik dan teratur. Beberapa warga Desa Samirplapan membuang sampah mereka di halaman sebelah rumah atau pada bak-bak bekas timba cat dan karung beras, bukan pada tempat pembuangan sampah. Namun, beberapa warga Desa Samirplapan sudah membuang sampah pada tempat sampah. Akan tetapi, tempat sampah tersebut mempunyai kapasitas penampungan sampah yang kurang. Hal tersebut bisa terlihat pada menumpuknya sampah di tempat sampah yang tidak sesuai dengan volume dan kapasitas penampungan maksimal di 
tempat sampah tersebut. Sampah yang dibuang dan dihasilkan oleh warga Desa Samirplapan paling banyak adalah sampah anorganik seperti bekas botol minuman, sampah bekas makanan, sampah bekas kardus botol minuman, dimana sampah anorganik tersebut sulit terurai oleh bakteri tanah.

Permasalahan sampah menjadi masalah yang paling utama dan harus segera diatasi. Pembuangan limbah sampah yang belum baik dan teratur dapat menimbulkan beberapa dampak serius bagi lingkungan dan kesehatan. Dampak belum baiknya pembuangan limbah sampah ke lingkungan dapat berupa dampak estetika dan pencemaran terhadap tanah. Dampak terhadap estetika muncul karena sampah yang berserakan dan menumpuk menjadi kurang enak untuk dipandang oleh mata dan menimbulkan bau tidak sedap yang dapat mengganggu keseharian warga Desa Samirplapan. Sedangkan, dampak pencemaran tanah muncul akibat sulit terurainya sampah anorganik ketika berada di dalam tanah. Sampah anorganik yang sulit terurai dalam tanah dapat mengurangi kesuburan tanah itu sendiri. Sehingga, kualitas tanah akan mengalami penurunan. Sampah yang menumpuk juga dapat menjadi masalah bagi kesehatan. Hal tersebut dikarenakan, sampah yang menumpuk akan disenangi dan digunakan sebagai tempat tinggal vektor penyakit seperti lalat dan tikus. Sehingga, nantinya akan menimbulkan beberapa penyakit akibat vektor penyakit seperti diare dan leptospirosis.

Permasalahan sampah tersebut dapat diatasi dengan dibentuknya manajemen bank sampah sebagi langkah awal dalam mewujudkan pembuangan sampah yang baik dan teratur. Dengan manajemen bank sampah, pemasalahan sampah di Desa Samirplapan dapat diatasi, sehingga menghindarkan warga dari penyakit, dan dapat meningkatkan pendapatan warga untuk mengatasi permasalahan ekonomi sekitar melalui proses yang akan dijalani.

\section{Pemecahan Masalah}

Kegiatan pengabdian kepada masyarakat dilaksanakan dengan beberapa kegiatan, yakni kegiatan bank sampah serta pelatihan membuat kerajinan dari sampah anorganik dan pembuatan takakura. Bank sampah dimaksudkan untuk memberikan solusi dari banyaknya sampah anorganik yang dan di wilayah Dusun Samir, sedangkan kegaiatan pelatihan pembuatan kerajinan dimaksudkan untuk memberikan pembekalan kepada warga untuk meningkatkan nilai jual dari sampah anorganik yang dihasilkan. Pelatihan takakura dimaksudkan sebagai solusi pada permasalahan sampah organik, sehingga warga secara maksimal dapat mengolah seluruh sampah yang dihasilkan.

\section{Sosialisasi dan Pelaksanaan Bank Sampah}

Rangkaian kegiatan diawali dengan sosialisasi mengenai program pengabdian yang akan dilaksanakan kepada kader dan perwakilan dari setiap RT. Sosialisasi dilakukan dengan pemaparan materi tentang bank sampah merupakan program nasional, penjelasan umum terkait bank sampah, alur pengeloaan sampah, dan lain-lain (Utami, 2013). Selain itu, kegiatan ini dimaksudkan agar para kader dapat membantu selama program pengabdian masyarakat ini sebagai perpanjangan tangan dari pelaksana program. Kader juga bertugas untuk mengajak warga pada pertemuan berikutnya untuk datang pada sosialisasi mengenai bank sampah dan mempraktekannya.

Kegiatan selanjutnya yakni sosialisasi mengenai bank sampah kepada warga Dusun Samir sebagai mitra yang akan menjalankan program bank sampah ini. Warga yang datang sejumlah 24 orang dan lokasi sosialisasi bertempat di rumah Kepala Dusun Samir. Dalam kegiatan ini juga dilakukan penggalangan komitmen warga yang bertujuan untuk menumbuhkan komitmen warga dalam menjalankan setiap kegiatan bank sampah. Pembentukan pengurus bank sampah terdiri dari ketua, wakil, sekretaris, dan bendahara. Setelah adanya sosialisasi ini, warga melakukan simulasi sesuai dengan materi yang telah diberikan. Sampai akhir kegiatan pendampingan, total jumlah anggota bank sampah yaitu 35 orang.

Kegiatan pengumpulan sampah dilakukan rutin tiap 2 minggu sekali dengan rincian kegiatannya yakni pemilahan sampah sesuai dengan jenisnya, penimbangan, dan penyetoran ke pengepul. Sampah yang dipilah antara lain kardus, kertas, plastik (botol, gelas, dan plastik berwarna), kaleng, dan besi. Penimbangan dilakukan oleh pengurus bank sampah yang telah terpilih, dan sampah yang terkumpul dicatat di Buku Besar dan Buku Tabungan masing-masing warga yang menjadi anggota bank sampah.

Hasil pengumpulan sampah tersebut dijual ke pengepul dan dana yang dihasilkan akan dikelola oleh pengurus bank sampah. Kebijakan dalam mengurus dana sesuai dengan kesepakatan yang telah ditentukan pada saat pembentukan pengurus.

Sebagai upaya memaksimalkan program bank sampah yang telah ada, maka dibangunlah tempat untuk menampuh sampah yang telah terkumpul sebelum dijual ke pengepul. Lokasi bank sampah terletak di samping rumah Kepala Dusun Samir (Gambar 1). Lokasi ini dipilih karena dinilai paling strategis. Pembangunan tempat untuk pengumpulan sampah dilakukan pada bulan Juli 2018.

\section{Pelatihan tentang Kerajinan dari Hasil} Pengelolaan Bank Sampah

Pelatihan kerajinan yang adakan dengan mengolah bahan bekas dari sampah anorganik. Sampah anorganik dijadikan kerajinan dimaksudkan 
untuk meningkatkan nilai jual dari sampah.

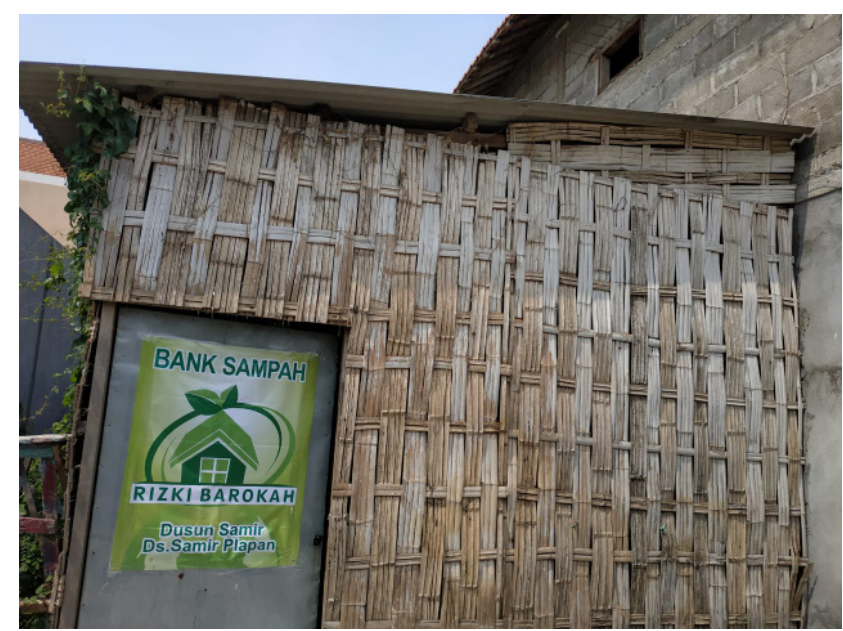

Gambar 1. Bank sampah di Desa Samirplapan.

\section{Pelatihan Pengolahan Sampah Organik dengan Menggunakan Teknik Takakura}

Kegiatan lainnya yang juga menjadi salah bagian dari program bank sampah ini adalah pelatihan pengolahan sampah organik. Jenis sampah organik banyak dihasilkan dari aktivitas rumah tangga, namun sering kali sampah organik hanya dibuang begitu saja tanpa melalui proses pengolahan. Sampah organik dapat dijadikan pupuk kompos yang bermanfaat untuk menyuburkan tanaman salah satunya dengan menggunakan teknik takakura. Ketika dihasilkan pupuk kompos dengan jumlah banyak maka dapat dijual untuk menambah pemasukan.

\section{Monitoring dan Evaluasi}

Monitoring dan evaluasi dilakukan pada setiap kegiatan yang dilaksanakan pada program bank sampah di lingkungan Dusun Samir. Keberhasilan pelaksanaan program pengabdian kepada masyarakat ini dapat dilihat dari bebrapa tolak ukur berikut ini:

a. Respon positif dari warga

Respon warga diukur melalui observasi selama program pengabdian kepada masyarakat dengan antusiasme warga yang tinggi, yakni rata-rata sebanyak 25 orang yang datang dalam setiap kegiatan yang diadakan dengan total jumlah peserta 35 orang. Mengadakan diskusi menyangkut kesan, pesan, kritik dan usulan dari warga mengenai kegiatan pengabdian kepada masyarakat ini.

b. Meningkatnya pengetahuan warga setelah sosialisasi bank sampah

Indikator pengetahuan warga dapat diukur melalui hasil post-test yang diadakan setelah sosialisasi mengenai bank sampah dan observasi saat berlangsungnya kegiatan pengumpulan sampah.

c. Meningkatnya keterampilan warga setelah pelatihan
Keterampilan peserta telah diobservasi saat pelatihan melalui tugas-tugas mengenai pembuatan takakura dan pembuatan kerajinan dari sampah anorganik.

\section{KESIMPULAN DAN SARAN}

Berdasarkan hasil kegiatan kemitraan kepada masyarakat di Desa Samirplapan, Kecamatan Duduk Sampeyan, Gresik dapat disimpulkan bahwa permasalahan sampah dapat diselesaikan jika dilakukan bersama, yang dimulai dari tingkatan terkecil yaitu rumah tangga. Pemilahan sampah yang dilakukan oleh masyarakat, dibedakan menjadi dua jenis, yaitu sampah organik dan sampah anorganik. Sampah organik diolah mandiri pada setiap rumah tangga menggunakan metode takakura, sedangkan sampah anorganik ditabung di bank sampah.

Kendala yang dialami selama pelaksanaan program yakni menarik minat warga yang masih belum bergabung dengan bank sampah, karena masih sebagian masyarakat di desa Samirplapan yang merasakan manfaat dari adanya bank sampah. Selain itu, kesulitan untuk menemukan pengepul yang mau mengambil sampah pada waktu yang tetap sesuai dengan jenis sampah yang dikumpulkan oleh masyarakat. Diharapkan akan ada kerja sama tetap antara pengepul dengan pengurus bank sampah agar mau mengambil sampah yang dikumpulkan oleh masyarakat dengan waktu yang rutin.

\section{UCAPAN TERIMA KASIH}

Kami mengucapkan banyak terimakasih kepada Kepala Desa Samirplapan, Duduk Sampeyan Gresik beserta seluruh warga sehingga kegiatan ini dapat terlaksana dengan baik. Penulis menyatakan tidak ada konflik kepentingan dengan pihak-pihak yang terkait dalam kegiatan pengabdian kepada masyarakat ini.

\section{DAFTAR PUSTAKA}

Kementerian Lingkungan Hidup. 2012. Peraturan Menteri Lingkungan Hidup Republik Indonesia Nomor 13 Tahun 2012 tentang Pedoman Pelaksanaan Reduce, Reuse dan Recycle Melalui Bank Sampah. Jakarta: Kementerian Lingkungan Hidup.

Pemerintah Republik Indonesia. 2012. Peraturan Pemerintah Republik Indonesia No. 81 Tahun 2012 tentang Pengelolaan Sampah Rumah Tangga dan Sampah Sejenis Sampah Rumah Tangga. Jakarta: Sekretariat Negara.

Rozak, A. 2014. Peran Bank Sampah Warga Peduli Lingkungan (WPL) dalam Pemberdayaan 
Perekonomian Nasabah. Skripsi. Jakarta: Fakultas Syariah dan Hukum, UIN Syarif Hidayatullah.

Utami, E. 2013. Buku Panduan Sistem Bank Sampah dan 10 Kisah Sukses. Jakarta: Yayasan Unilever Indonesia. 